\title{
Vplyv plyometrického tréningu na zmeny silových schopností vrcholových volejbalistiek
}

\section{Influence of plyometric trainings for changes of strength abilities of female volleyball players}

\author{
Marián Vanderka, Martin Kojnok, Katarína Longová
}

Fakulta telesnej výchovy a športu Univerzity Komenského v Bratislave, Slovensko

\begin{abstract}
Abstrakt
Ciel’om dvojskupinového časovo súbežného 6-týždñového experimentu bolo porovnat' vybrané typy plyometrického tréningu s gradáciou prídavnej hmotnosti (EXP1) a s gradáciou výšky zoskoku (EXP2) pri cvičení zoskok-výskok a ich účinnost’ na zmeny vybraných prejavov silových schopností. Hodnotili sme úroven̆ vertikálneho výskoku s protipohybom (CMJ), bez protipohybu (SJ) a priemerný silový gradient pri cvičení drep s pokrčením v kolennom kíbe $90^{\circ} v$ izometrických podmienkach v intervaloch 0-50 ms (RFD50) a v 0-200 ms (RFD200) od počiatku maximálnej izometrickej kontrakcie. Výsledky preukázali, že v CMJ sme u skupiny $s$ gradáciou prídavnej hmotnosti EXP1 zaznamenali zlepšenie o 1,01 cm $(3,5 \%)(p<0,01)$. EXP2 sa zlepšila $v$ priemere o $1,78 \mathrm{~cm}(5,5 \%)(p<0,05)$. SJ sa v EXP1 v priemere zlepšila o 0,94 cm $(3,5 \%)(p=n . s),$.$v EXP2$ o $1,91 \mathrm{~cm}(6,6 \%)(p<0,05)$. V RDF50 bol priemerný prírastok zaznamenaný po perióde tréningu u EXP1 1,03 N.ms - $^{-1}(26,08 \%)$ (p = n.s.) a u EXP2 0,57 N.ms ${ }^{-1}(16,39 \%)(p<0,05)$. V RFD200 u EXP1 bol priemerný prírastok po perióde tréningu 2,51 N.ms $s^{-1}(20,91 \%)$ ( $\left.<<0,01\right)$, zatial' čo EXP2 sa v priemere zlepšila o 1,05 $N . m s^{-1}(10,04 \%)(p=n . s$.$) . Na základe získaných poznatkov odporúčame pre zlepšenie úrovne vertikálneho$ výskoku s protipohybom aplikovat postup s pridávaním doplnkovej zát’aže v excentrickej časti. Pre výskok bez protipohybu a kratšie časové intervaly silového gradientu odporúčame použivat'systém s postupným zvyšovaním výšky zoskoku.
\end{abstract}

\begin{abstract}
The aim two groups time parallel 6-week experiment was to compare selected types of plyometric training. One group trained with gradation of external weight loading in eccentric phase (EXP1) and the second group increased drop height (EXP2) during drop jump training. We compared their effects on changes in selected strength abilities. We assessed the level of countermovement vertical jump height (CMJ), standing vertical jump height (SJ) and average force gradient in squat exercises with the knee joint in $90^{\circ}$ by maximal isometric contraction at intervals of 0-50 ms (RFD50) and 0-200 $\mathrm{ms}$ (RFD200). The results showed that in CMJ EXP1 had improved by $1.01 \mathrm{~cm}(3.5 \%)(p<0.01)$. EXP2 improved by an average of $1.78 \mathrm{~cm}(5.5 \%)(p<0.05)$. SJ in EXP1 average improved by $0.94 \mathrm{~cm}(3.5 \%)(p=n . s$.$) in EXP2 by 1.91 \mathrm{~cm}(6.6 \%)(p<0.05)$. In RDF50 the average increase observed after a period of training in EXP1 $1.03 \mathrm{N.ms^{-1 }}(26.08 \%)(p=n . s$.$) and EXP2$ $0.57 \mathrm{~N} . \mathrm{ms}^{-1}(16.39 \%)(p<0.05)$. In the EXP1 RFD200 the average increase was $2.51 \mathrm{~N}^{\mathrm{m} \mathrm{m}^{-1}}$ after a period of

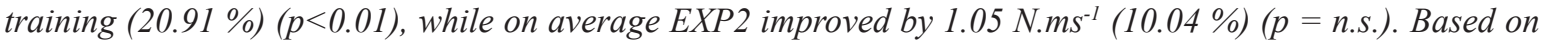
these results we recommend to improving of vertical jump height with a countermovement and force gradient in longer intervals $(200 \mathrm{~ms})$ to apply the external weight in the form of small dumbbells in eccentric phase of drop jump training. To standing jump height development and shorter time intervals of force gradient (50 ms) is recommended to use a gradual increase in height of drop in plyometric training.
\end{abstract}

Kl'účové slová: volejbal, ženy, silové schopnosti, plyometria, výška výskoku, silový gradient

Key words: volleyball, women, strength abilities, plyometrics, vertical jump height, force gradient (RFD) 


\section{ÚVOD}

Plyometrický tréning zvyšuje svalovú silu a výkon a je účinný najmä vtedy, ked’ je navrhnutý tak, aby kopíroval špecifické pohyby vykonávané počas podávania športového výkonu. Pozitívne účinky takéhoto plyometrického tréningu na výšku vertikálneho výskoku a iné parametre sily preukázali napr. Boroujerdi (2009) a Hosseini (2012).

Lees \& Fahmi (1994) tvrdia, že plyometrický tréning rozvíja schopnost' svalov produkovat' vyšší výkon a posilňuje svalovo - šl'achový a oporný pohybový aparát vzhl’adom na sily, ktoré sú na neho kladené počas plyometrického tréningu.

Už predtým Steben \& Steben (1981) predpokladali, že k zvýšeniu výkonu pri vertikálnom výskoku pri cvičení zoskok-výskok dochádza vd’aka zrýchleniu amortizačnej fázy, ktorá je elektromechanickým oneskorením od začiatku excentrickej po začiatok koncentrickej fázy pohybu.

Ebben et al. (2010) dokázali signifikantný vplyv plyometrického tréningu na zlepšenie vo vertikálnom výskoku $(\mathrm{p}<0,05)$ a aj v maximálnom výkone $(\mathrm{p}<0,01) \mathrm{u}$ žien.

Villarreal et al. (2008) skúmali frekvenciu podnetov plyometrického tréningu za týždeň a z výsledkov vyplýva, že ako efektívnejší model plyometrického tréningu sa preukazuje stredný počet podnetov, tj. 2 podnety za týždeň.

Khlifa et al. (2010) sa zaoberali účinnost'ou plyometrického tréningu bez a s prídavnou hmotnost'ou u basketbalistov. Obe experimentálne skupiny dosiahli zlepšenie vo všetkých testoch, avšak experimentálna skupina, ktorá vykonávala plyometrický tréning s prídavnou hmotnostou preukázala významne vyššie prírastky oproti skupine bez prídavnej hmotnosti.

Miller et al. (2006) v dvojskupinovom experimente zistili aj štatisticky významný pozitívny vplyv plyometrického tréningu na výkony v 3 testoch agility. V anglicky hovoriacich krajinách sú to nielen testy na výberové reakčné schopnosti u nás známe ako agility test, ale aj testy na rýchlost' so zmenami smeru kde sa zložka rozhodovania nenachádza (tzv. T-test a Ilinois agility test). Tréning trval 6 týdňov, pričom pozostával z rôznych cvičení v dvoch tréningových jednotkách do týždňa s objemom od 90 do 120 opakovaní v jednej tréningovej jednotke.

Plyometrickým tréningom sa optimalizuje využitie reflexno - elastických vlastností, ale zlepšujú sa aj procesy, kde dochádza k adaptácii na neuroregulačnej báze lepšou synchronizáciou aktivácie motoneurónov, ako aj zlepšením vzrušivosti spinálneho kortexu (Potteiger et al., 1999).

Z doterajších poznatkov vyplýva, že optimálna výška zoskoku pri plyometrickej metóde pri cvičení zoskok výskok zodpovedá približne výške výskoku s protipohybom. Boli identifikované parametre akumulačno - rekuperačného cyklu, pri ktorých je aktivovaný ochranný mechanizmus pohybového aparátu. Ked' trvá akumulačná fáza viac ako 150 ms prestáva byt’ akumulačno - rekuperačný cyklus efektívny (Slamka, 2000).

Pri zvyšovaní zat’aženia $v$ tréningu zoskoku výskoku sa v praxi uplatňujú dva základne princípy. V našom prípade ide o zvyšovanie intenzity zat’aženia a nie objemu, pretože objemový prístup bol nie len v praxi, ale aj na základe vedeckých poznatkov už dávnejšie prekonaný.

Intenzifikáciu možno realizovat' bud' postupným zvyšovaním výšky zoskoku, alebo pridávaním doplnkového závažia.

Obidva postupy so sebou prinášajú špecifické problémy. V prípade zvyšovania výšky zoskoku je pravdepodobné aktivovanie ochranného mechanizmu a $\mathrm{v}$ prípade pridávania závažia je problematické načasovanie jeho odhodenia vo fáze prechodu z excentrickej do koncentrickej kontrakcie.

Vo vedeckej literatúre sa nám nepodarilo nájst' taký výskum, ktorý by porovnával efekty takýchto dvoch spôsobov realizácie plyometrického tréningu. Pretože sa v praxi využíva už dlhšie pokúsili sme sa kvantifikovat', na základe experimentálneho prístupu, rozdielnosti v ich efektoch na zmeny vybraných silových schopností, ktoré možno považovat' za jedny z limitujúcich motorických faktorov v štruktúre športového výkonu volejbalistiek.

$\mathrm{Na}$ základe teoretických východísk a skúseností z tréningovej praxe môžeme predpokladat', že: v skupine realizujúcej cvičenie zoskok - výskok s gradáciou prídavnej hmotnosti zaznamenáme po perióde tréningu väčšie prírastky v teste vertikálny výskok s protipohybom (CMJ) a v priemernom silovom gradiente v časovom intervale 200ms (RFD200) od počiatku maximálnej izometrickej kontrakcie. Naproti tomu skupina zvyšujúca zat’aženie pridávaním výšky zoskoku bude mat' signifikantne väčšie prírastky v teste vertikálny výskok bez protipohybu (SJ) a priemernom silovom gradiente v časovom intervale 0-50ms (RFD50) od počiatku maximálnej izometrickej kontrakcie. 


\section{CIEL}

Ciel'om výskumu bolo porovnat' účinnost' dvoch typov plyometrického tréningu (s gradáciou prídavnej hmotnosti a s gradáciou výšky zoskoku) pri cvičení zoskok - výskok na vybrané prejavy sily (vertikálneho výskoku s protipohybom a bez protipohybu a silového gradientu). Kvantifikáciou týchto rozdielov z hl'adiska rôznych spôsobov vykonania chceme prispiet’ k objektivizácii rozvoja silovo - rýchlostných schopností.

\section{METODIKA}

Výskum sme realizovali prostredníctvom dvojskupinového časovo súbežného dvojfaktorového pedagogického experimentu. Súbor tvorilo 15 volejbalistiek extraligy žien Slavie EU Bratislava. Probandky boli rozdelené do experimentálnych skupín na základe zámerno-náhodného výberu, tak aby boli ich výkony vo vertikálnom výskoku na vstupnom meraní porovnatel'né. Tým sme zvíšili vnútornú validitu experimentu.

Experimentálne činitele boli aplikované v dížke trvania 6 týždňov z frenvenciou experimentálnych podnetov 2 krát za týždeň. Experimentálny činitel' predstavovalo cvičenie zoskok - výskok s počtom opakovaí 6 a počtom sérií 6 . Probandky realizovali každý výskok po zoskoku maximálnym úsilým. Nevýznamné zmeny v intenzite sme zabezpečili dostatočným odpočinkom, ktorý medzi sériami predstavoval 3 minúty aktívneho odpočinku realizovaného medzichôdzou. Výška zoskoku pri cvičení zoskok - výskok bola stanovená pre každú probandku individuálne na základe výšky vertikálneho výskoku s protipohybom na výskokovom ergometri FiTRO jumper.

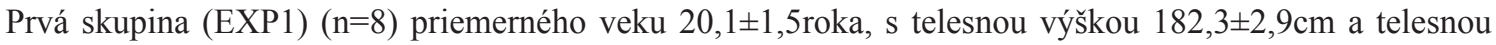
hmotnost'ou 75,0 $44,2 \mathrm{~kg}$ vykonávala cvičenie zoskok - výskok s postupným pridávaním doplnkovej hmotnosti (Obr. 1), ktorú po zoskoku odhadzovali a výskok realizovali bez nej so švihovou prácou paží. Vel'mi dôležitým faktorom sa $v$ tomto prípade javí načasovanie (timing) odhodenia prídavnej žát’aže (jednoručných činiek). Naše probantky realizovali nácvik, počas ktorého získali takú zručnost', ktorá umožňovala pustit' závažie po kontakte s podložkou čo najbližšie k momentu prechodu z excentrickej do koncentrickej kontrakcie. Prvé dva týždne vykonávali cvičenia zoskok - výskok s prídavnou hmotnost'ou 5\% z vlastnej telesnej hmotnosti, 3. a 4. týždeň s prídavnou hmotnost'ou $10 \%$ z vlastnej telesnej hmotnosti a posledné dva týždne s $15 \%$ z vlastnej telesnej hmotnosti.

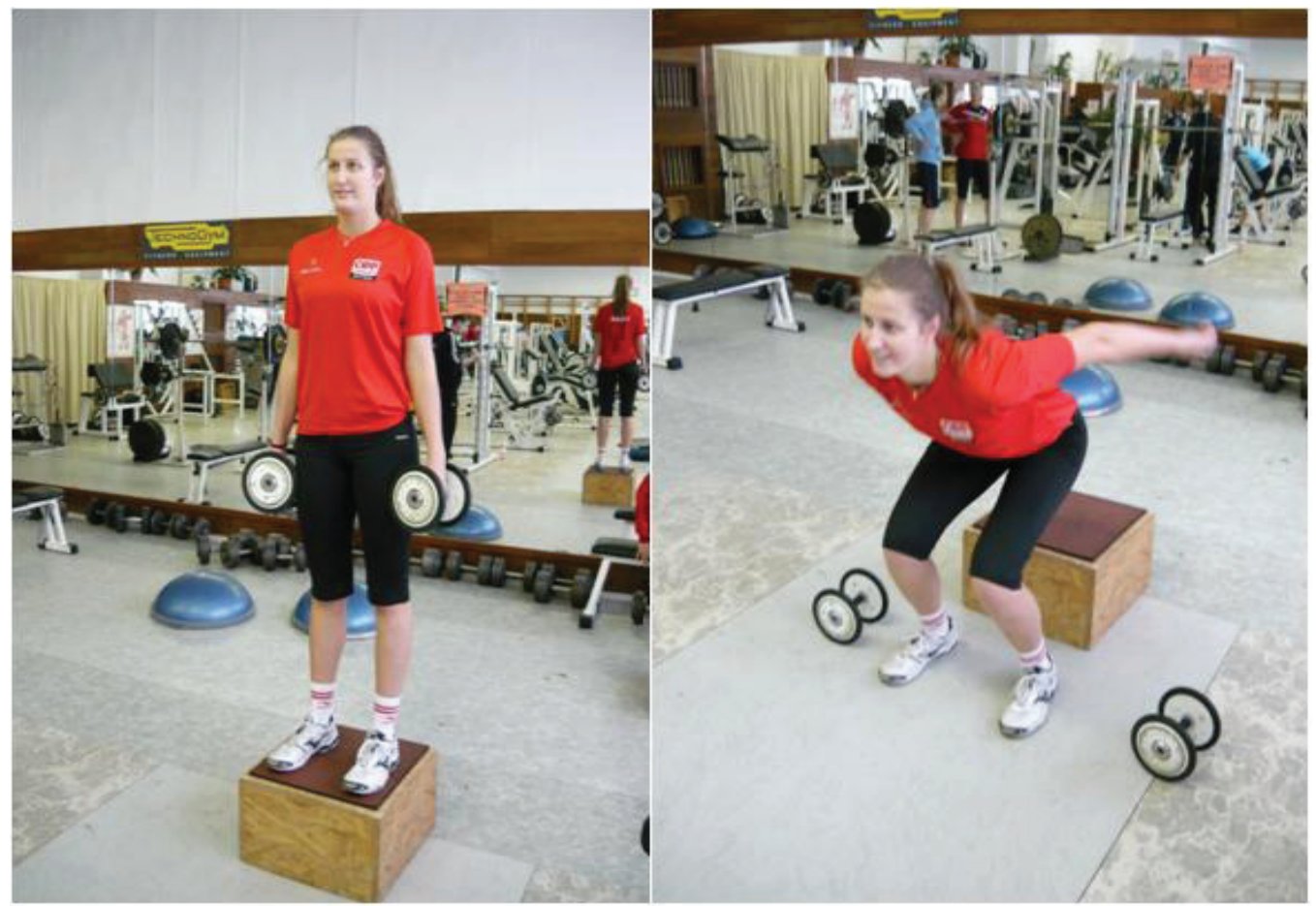

Obr. 1: Cvičenie zoskok - výskok s postupným pridávaním doplnkovej hmotnosti 


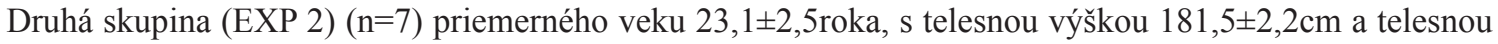
hmotnost'ou $71,1 \pm 3,2 \mathrm{~kg}$ vykonávala cvičenie zoskok - výskok s postupným pridávaním výšky zoskoku a výskok (Obr. 2) realizovali so švihovou prácou paží. Prvé dva týždne vykonávali cvičenia zoskok - výskok s prídavnou výškou zoskoku $10 \%$ z vlastného vertikálneho výskoku s protipohybom, 3. a 4. týždeň s s prídavnou výškou zoskou $20 \%$ z vlastného vertikálneho výskoku s protipohybom a posledné dva týždne s prídavnou výškou zoskou $30 \%$ z vlastného vertikálneho výskoku s protipohybom.

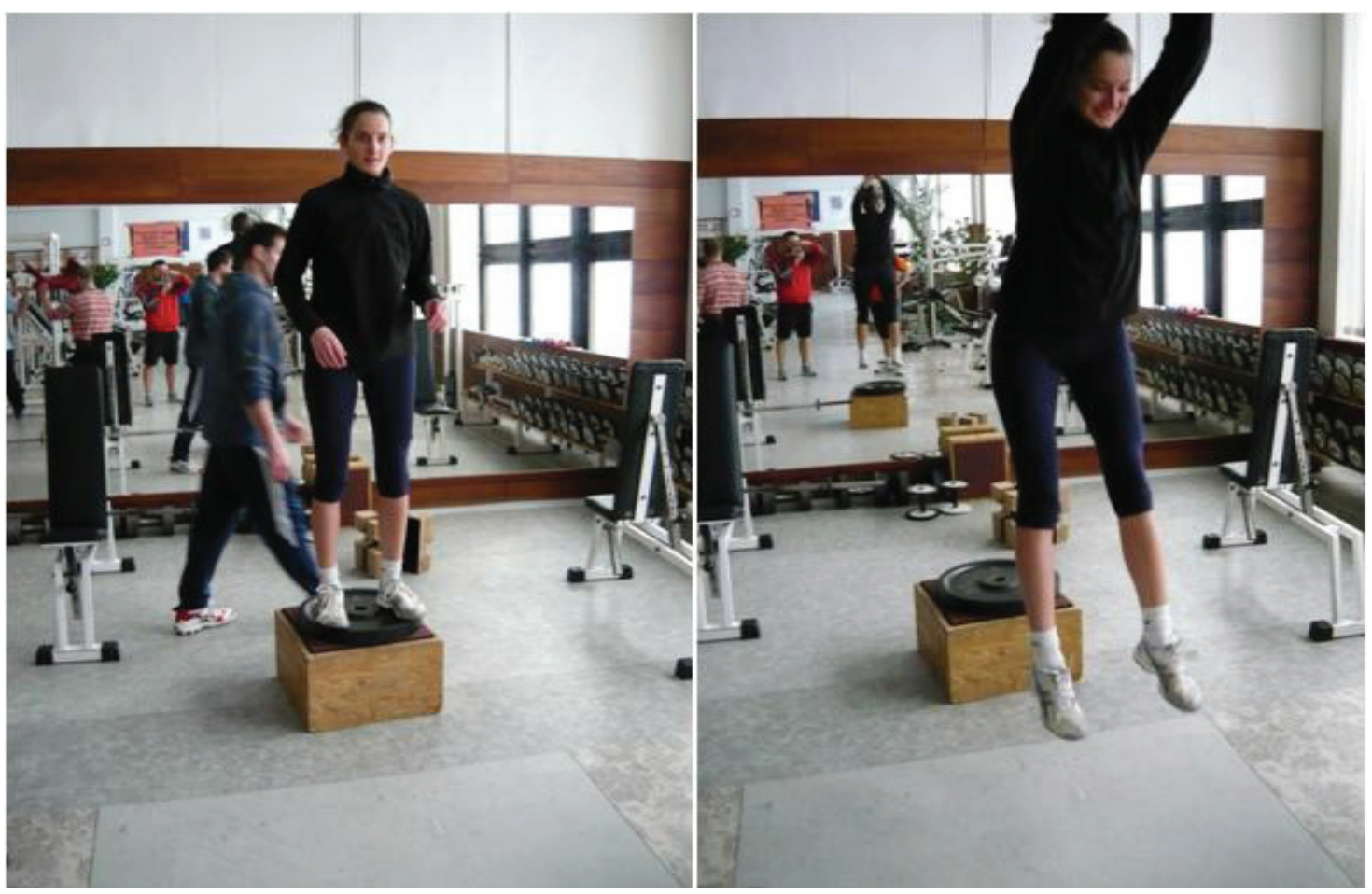

Obr. 2: Cvičenie zoskok-výskok s postupným pridávaním výšky zoskoku

Vstupné (4.1.2012) a výstupné (23.2.2012) testovania sme vykonávali na Katedre kinantropológie FTVŠ UK v Bratislave. Pred testovaním bolo zaradené rozcvičenie, ktoré bolo pri vstupnom a výstupnom meraní totožné a trvalo 15 minút.

Údaje o výške vertikálneho výskoku s protipohybom (CMJ) (obr. 3) a bez protipohybu (SJ) sme získavali meraním jednotlivých probandiek pomocou zariadenia FiTRO jumper, realizované boli výskoky z miesta po jednom, nie za sebou idúce opakované výskoky. Na jednotlivé spôsoby realizácie vertikálneho výskoku mali probandky jeden zácvičný a dva merané pokusy, počítal sa lepší z nich. Probandky sa po udelení pokynu postavili na FiTRO jumper, horné končatiny boli fixované o boky a na vlastný podnet vykonali jeden vertikálny výskok s protipohybom, alebo bez protipohybu. Pri vykonávaní pokusov bez protipohybu sme dbali na správne prevedenie, ak nastal protipohyb pred odrazom pokus bol neplatný a probandka ho realizovala ešte raz. Medzi jednotlivými spôsobmi (CMJ a SJ) a pokusmi mali probandky minimálne 1 minútový interval odpočinku. Namerané hodnoty sme ukladali v programe FiTRO jumper a následne s nimi d’alej pracovali.

Priemerný silový gradient (RFD) sme merali v izometrickom režime v podrepe s pokrčením v kolennom kíbe $90^{\circ}$ na dynamometrickej platni. Dynamometrická platňa je spojená s 12 bit AD convertorom a softvérom firmy Fitronic.sk, ktorý umožňuje vypočítat’ hodnoty silového gradientu (Schickhofer \& Cvečka, 2011) (Obr. 


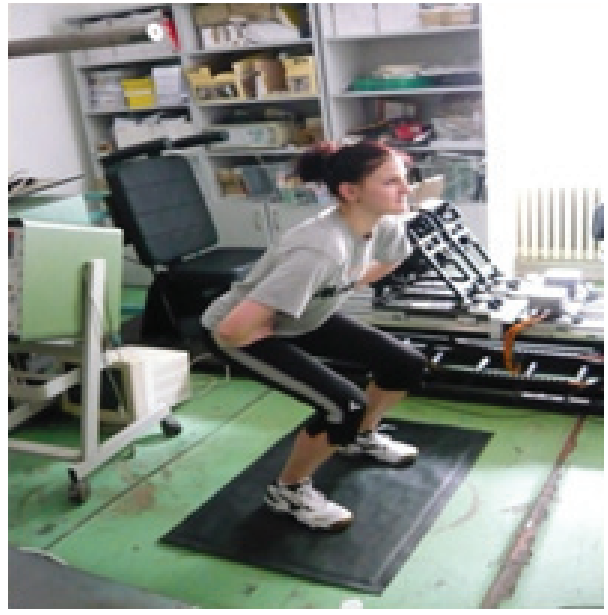

Obr. 3: Vertikálny výskok

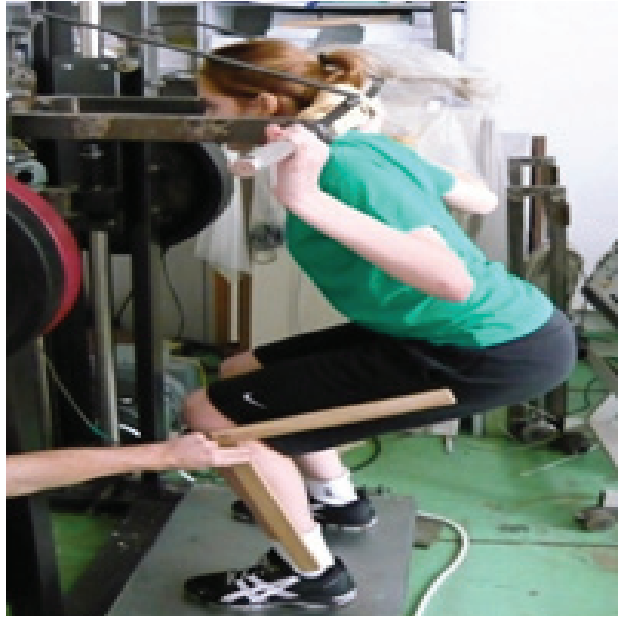

Obr. 4: Meranie silového gradientu s $90^{\circ}$ uhlom v kolennom kíbe

Pred testovaním sme FiTRO force plate položili vodorovne pod Smithov stroj, tak aby sa nehýbala a nakalibrovali sme ju. Kalibrácia prebiehala uložením 100 kg závažia vo forme kotúčov olympijskej činky na plochu dynamometrickej platne. Na Smithov stroj sme následne naložili tol'ko závažia, aby počas testovania nedošlo k žiadnemu pohybu činky (aby probantky neboli schopné pohnút' so závažím). Probandky sa po vyzvaní postavili na FiTRO force plate a následne sme nastavili výšku Smithovho stroja tak, aby uhol v kolennom kíbe bol $90^{\circ}$. Potom testovaná osoba vykonala zácvičný pokus. Po ňom nasledoval interval odpočinku 2 minúty a následne bol realizovaný prvý pokus. Testované probandky sa na vyzvanie postavili na FiTRO force plate a zotrvali v pokoji s jemným dotykom činky. Boli inštruované na povel zatlačit’ čo najväčšou silou, ale najmä čo najrýchlejšie, do činky maximálnym úsilím v trvaní minimálne 3 sekundy. Každá probandka mala dva pokusy, pričom sa počítal lepší z nich. Medzi jednotlivými pokusmi sme dodržiavali 2 minútový interval odpočinku. Z nameraných hodnôt sme vypočítavali hodnotu sily vyprodukovanej v časovom intervale $0-50 \mathrm{~ms}$ (RFD50) a 0-200ms (RFD200) od počiatku maximálnej izometrickej kontrakcie. Tieto hodnoty sme odčítali od hodnôt gravitačnej sily a dostali sme reálne hodnoty sily tlaku vyvíjaného na platňu, ktoré sme vydelili počtom milisekúnd (50 a 200) a výsledkom bol priemerný silový gradient v N.ms ${ }^{-1}$. Namerané hodnoty sme ukladali v programe FiTRO force a následne s nimi d’alej pracovali.

$\mathrm{Na}$ vyhodnotenie významnosti variability údajov medzi vstupnými a výstupnými hodnotymi vrámci jednotlivých skupín sme použili Wilcoxonov T - test. Na vyhodnotenie významnosti rozdielov medzi priemrnými prírastkami v sledovaných parametroch medzi skupinami sme použili Mann - Whitneyho U - test.

\section{VÝSLEDKY A DISKUSIA}

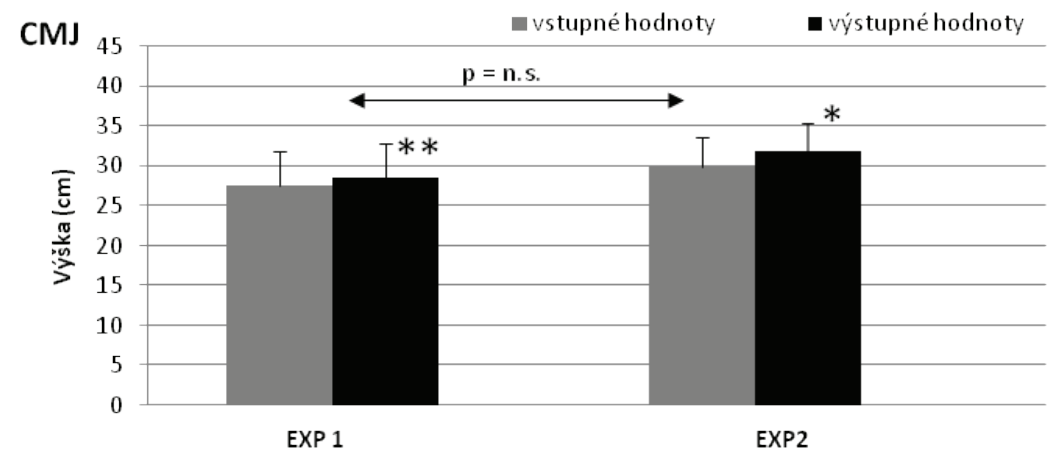

Obr. 5: Priemerné hodnoty a smerodajné odchýlky pri vstupnom a výstupnom meraní v teste ,vertikálny výskok s protipohybom “ $(C M J)(* *-\mathrm{p}<0,01 ; *-\mathrm{p}<0,05)$ 
Vo vertikálnom výskoku s protipohybom sme u skupiny s gradáciou prídavnej hmotnosti (EXP1) zaznamenali vstupné hodnoty $27,475 \pm 4,37 \mathrm{~cm}$, výstupné hodnoty $28,4875 \pm 4,33 \mathrm{~cm}$, čo predstavuje zlepšenie o $1,01 \mathrm{~cm}$ $(3,5 \%)(\mathrm{p}<0,01)$.

U skupiny $2 \mathrm{~s}$ gradáciou výšky zoskoku (EXP2) sme zaznamenali vstupné hodnoty $30,02 \pm 3,66 \mathrm{~cm}$, výstupné hodnoty $31,8 \pm 3,54 \mathrm{~cm}$, to predstavuje zlepšenie o $1,78 \mathrm{~cm}(5,5 \%)(\mathrm{p}<0,05)$.

Tieto naše zistenia korelujú s predchádzajúcimi štúdiami (Boroujerdi, 2009; Hosseini, 2012), ktorí taktiež preukázali pozitívny vplyv plyometrického tréningu na výkon vo vertikálnom výskoku.

Pri overovaní významnosti rozdielov v priemerných prírastkoch experimentálnych súborov sa tieto ukázali ako štatisticky nevýznamné, aj ked’ štatisticky signifikantné zlepšenie zaznamenala skupina s gradáciou prídavnej hmotnosti. K podobným výsledkom sa dopracovali vo svojom výskume aj Khlifa et al, (2010). Zistili, že skupina, ktorá vykonávala plyometrický tréning s prídavnou hmotnost’ou mala významne vyššie prírastky vo vertikálnom výskoku v porovnaní so skupinou trénujúcou zoskok výskok bez prídavnej hmotnosti. Vysvetlenie vidíme v pravdepodobne lepšej akumulácie elastickej energie pri cvičení s prídavnou zátažou. Takýto tréning vytvára predpoklady na využitie väčšieho množstva elastickej energie aj v prirodzených podmienkach, čo sa môže prejavit' v efektívnom zvýšení výšky výskoku, jedného z limitujúcich ukazovatel’ov motorického výkonu nie len vo volejbale.

$$
\text { SJ घstupnéhodnoty vístupnéhodnoty }
$$

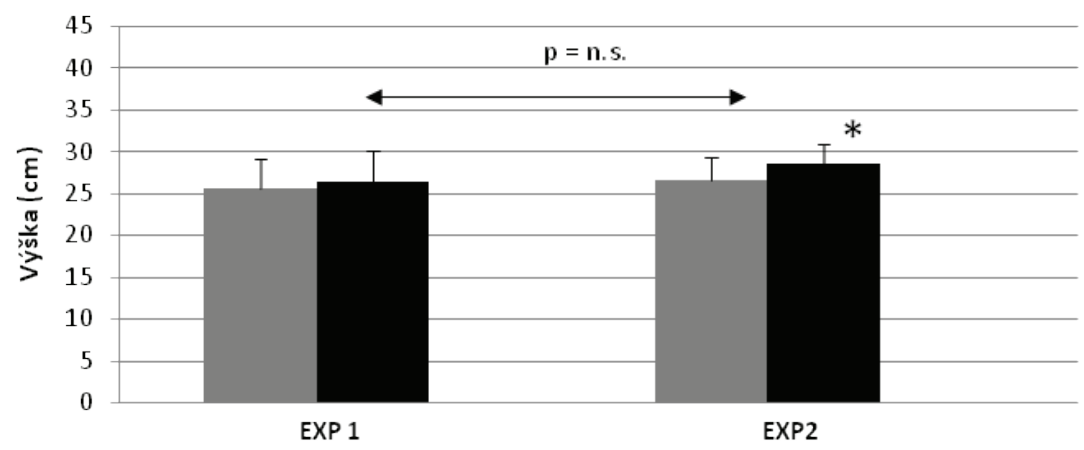

Obr. 6: Priemerné hodnoty a smerodajné odchýlky pri vstupnom a výstupnom meraní v teste „,vertikálny výskok bez protipohybu“ (SJ) (**-p<0,01; *-p<0,05)

Vo vertikálnom výskoku bez protipohybu sme u EXP1 s gradáciou prídavnej hmotnosti zaznamenali vstupné hodnoty $25,525 \pm 3,54 \mathrm{~cm}$, výstupné hodnoty, $26,463 \pm 3,7 \mathrm{~cm}$, zlepšenie predstavovalo v priemere $0,94 \mathrm{~cm}$ $(3,5 \%)(p=n . s$.$) .$

U skupiny EXP2 s gradáciou výšky zoskoku sme zaznamenali vstupné hodnoty $26,671 \pm 2,61 \mathrm{~cm}$, výstupné hodnoty $28,586 \pm 2,34 \mathrm{~cm}$, zlepšenie bolo v priemere o $1,91 \mathrm{~cm}(6,6 \%)(\mathrm{p}<0,05)$.

Markovic (2007) uvádza vo svojej metaanalýze o účinnosti plyometrického tréningu niektoré metodologické nedostatky spojené so špecificitou zat’aženia a následného preukazovania zmien testovaním. V našom prípade išlo o test bez švihu paží a s privel'kým pokrčením v kolennom kíbe. Na to hráčky neboli zvyknuté a ani to v tréningu nestimulovali. Ako uvádza Markovic hráčky dosahujú vyššie hodnoty vertikálneho výskoku bez protipohybu zo stoja iba s malým pokrčením v kolennom kíbe ako z hlbšieho podrepu a to signifikantne.

D̆alším vysvetlením toho, že skupina s gradáciou výšky zoskoku sa významne zlepšila vo výskoku bez protipohybu je aj fakt, že bez prídavnej hmotnosti sa využíva menšie množstvo elastickej energie aj napätie v zat'ažovaných svaloch je menšie, čiže aj reflexná odpoved' je pravdepodobne menšia. Toto všetko vytvára prepoklady na to, aby bola viac stimulovaná koontrakcia - zväčšenie množstva zapájaných motorických jednotiek, čo sa prejavilo pozitívne práve v zmenách výšky vertikálneho výskoku bez protipohybu (SJ).

$\mathrm{V}$ priemernom silovom gradiente $\mathrm{v}$ časovom intervale 0-50ms (RDF50, Obr. 7) sme u skupiny $1 \mathrm{~s}$ gradáciou prídavnej hmotnosti (EXP1) zaznamenali vstupné hodnoty 2,93 $\pm 1,03 \mathrm{~N} \cdot \mathrm{ms}^{-1}$, výstupné hodnoty 3,96 $\pm 1,17$ N.ms ${ }^{-1}$. Priemerný prírastok zaznamenaný v tomto parametri po perióde tréningu bol $1,03 \mathrm{~N} . \mathrm{ms}^{-1}$, čo predstavuje $26,08 \%$. Tento percentuálne pomerne vel'ký priemerný prírastok napriek tomu nebol štatisticky významný $(\mathrm{p}=$ n.s.), čo možno pripísat’ nerovnomernému rozdeleniu dát $\mathrm{v}$ počtom malom súbore. Bola aj probandka čo sa 
zhoršila, čo v štatistickom hodnotení zohráva významnú úlohu.

U skupiny $2 \mathrm{~s}$ gradáciou výšky zoskoku (EXP2) sme zaznamenali vstupné hodnoty 2,92 $\pm 1,77$ N.ms ${ }^{-1}$, výstupné hodnoty $3,50 \pm 1,90 \mathrm{~N} \cdot \mathrm{ms}^{-1}$, rozdiel $\mathrm{v}$ absolútnych hodnotách predstavoval $0,57 \mathrm{~N} . \mathrm{ms}^{-1}, \mathrm{v}$ relatívnych hodnotách to bol prírastok o $16,39 \%(\mathrm{p}<0,05)$.

Skupina zvyšujúca intenzitu zat’aženia $\mathrm{v}$ mezocykle gradáciou výšky zoskoku dosiahla signifikantné zlepšenie RFD50 pravdepodobne špecifickou adaptáciou, ktorá spôsobila utlmenie ochranného mechanizmu. Tento ochranný mechanizmus riadený senzorom (Golgiho orgán) v šl'achách má za úlohu pri vysokom napätí chránit' svalovo-šlachový aparát pred poškodením tak, že reflexne vypína kontrakciu. Na základe našich výsledkov, môžeme konštatovat', že tréningom s postupným zvyšovaním výšky zoskoku môže dôjst' $\mathrm{k}$ jeho utlmeniu. Dôkazom toho je významné zlepšenie gradientu v prvých milisekundách maximálnej izometrickej kontrakcie v $90^{\circ}$ uhle v kolennom kíbe.

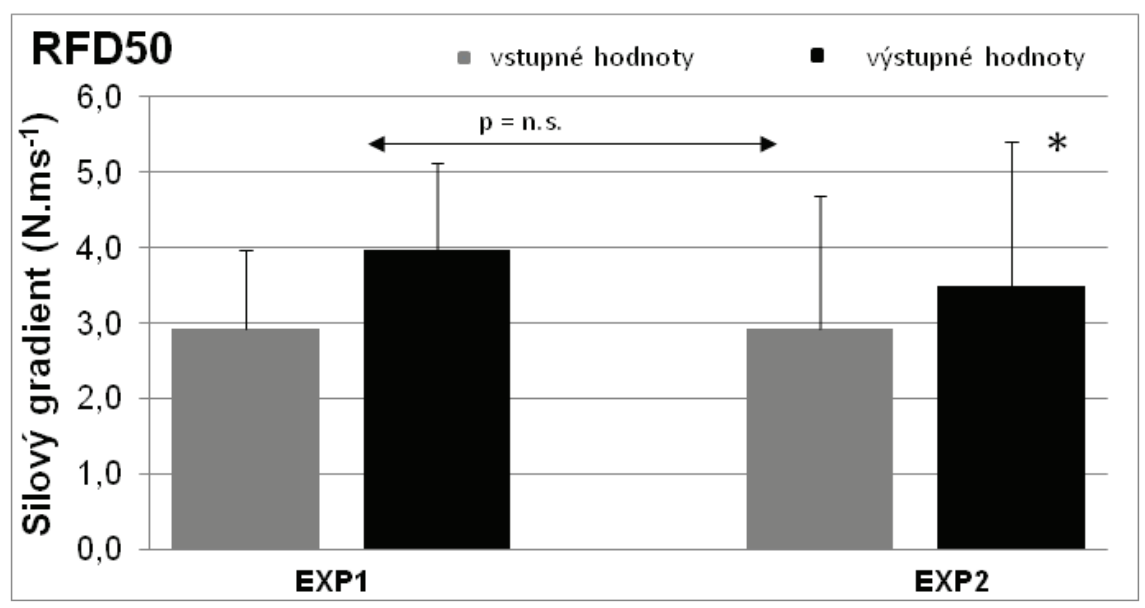

Obr. 7: Priemerné hodnoty a smerodajné odchýlky pri vstupnom a výstupnom meraní v teste , priemerný silový gradient “ v časovom intervale 0-50 ms (RFD50) (**-p <0,01; * $p<0,05)$

V našich predchádzajúcich výskumoch sme preukázali, že priemerný silový gradient v intervale 0-50 ms je pri pokrčení $90^{\circ} \mathrm{v}$ kolennom kíbe významne menší ako $\mathrm{v}$ iných uhloch $50^{\circ} \mathrm{a} 140^{\circ}$. Vysvetlenie sme našli v práci Escamilla et al. (1998) ktorí zistili, že $90^{\circ}$-vé pokrčenie v kolennom kíbe má za následok zväčšovanie tlaku v spomínanej oblasti a podobne aj Zawieja (2008) uvádza, že pri podrepe v uhle $90^{\circ}$ je najväčší tlak v kolennom kíbe. Je vysoko pravdepodobné, že v krátkom časovom úseku $(0-50 \mathrm{~ms})$ nie je preto možné produkovat' väčšie hodnoty silového gradientu $\mathrm{v} 90^{\circ}$ uhle $\mathrm{v}$ porovnaní $\mathrm{s}$ inými vel'kost’ami pokrčenia, lebo $\mathrm{v}$ podrepe je čas 0-50ms prikrátky na to, aby sa prekonal spomínaný tlak v kolennom kĺbe. Tlak spôsobuje to, že sa aktivizujú spätnoväzobné mechanizmy ochrany prostredníctvom prorpioreceptorov, ktoré pri nadhraničných hodnotách napätia na určitú krátku dobu reflexne utlmia kontrakciu. Po uplynutí tejto kritickej doby prevládne vedomá stimulácia produkcie sily a príslušné svalové skupiny začnú produkovat' silu. Zvyšovaním výšky zoskoku tak pravdepodobne dochádza $\mathrm{k}$ zníženiu citlivosti ochranného mechanizmu, čo sme preukázali významným zlepšením RFD50 v skupine EXP2.

Slamka (2000) sa vo svojej práci venoval hl’adaniu optimálnej výšky zoskoku pri cvičení zoskok výskok a zistil, že ak výška zoskoku presiahne hranicu približne rovnajúcu sa výške pri CMJ nastáva výrazné predíženie trvania opornej fázy a aj výška následného výskoku sa znižuje. Vysvetl'uje to práve aktiváciou ochranného mechanizmu. Z nášho výskumu vyplynulo, že je možne postupným zvyšovaním výšky zoskoku aj nad túto hranicu dosiahnut' zvýšenie výkonu pri výskoku bez protipohybu ako aj zlepšenie silového gradientu RFD50. To je možné pripísat' adaptácii v oblasti utlmenia ochranného mechanizmu. Objektívnejšie dôkazy o správnosti našej interpretácie by bolo možné získat' napríklad sledovaním aktivácie svalových skupín (EMG), avšak aj táto metodika, pokial' nie je riešená invazívne vnútro svalovo, je zat'ažená pomerne vel'kou chybou merania, takže informácie o vonkajšej intenzite (výška výskoku a RFD) nám poskytujú pomerne spol’ahlivú informáciu, z ktorej je možné dedukovat' isté súvislosti pomerne objektívne.

Útlm ochranného mechanizmu je z hl'adiska podávania rýchlostno-silového výkonu pozitívom, avšak 
môže znamenat' aj zvýšenie rizika poškodenia svalovo-šl'achového aparátu, čo nie je žiaduce. Preto treba pri dávkovaní zat'aženia zvyšovat' intenzitu opatrne a v kondičnej príprave realizovat' aj preventívne opatrenia prostredníctvom iných foriem silového tréningu, napríklad excentrickým a maximálne silový tréningom.

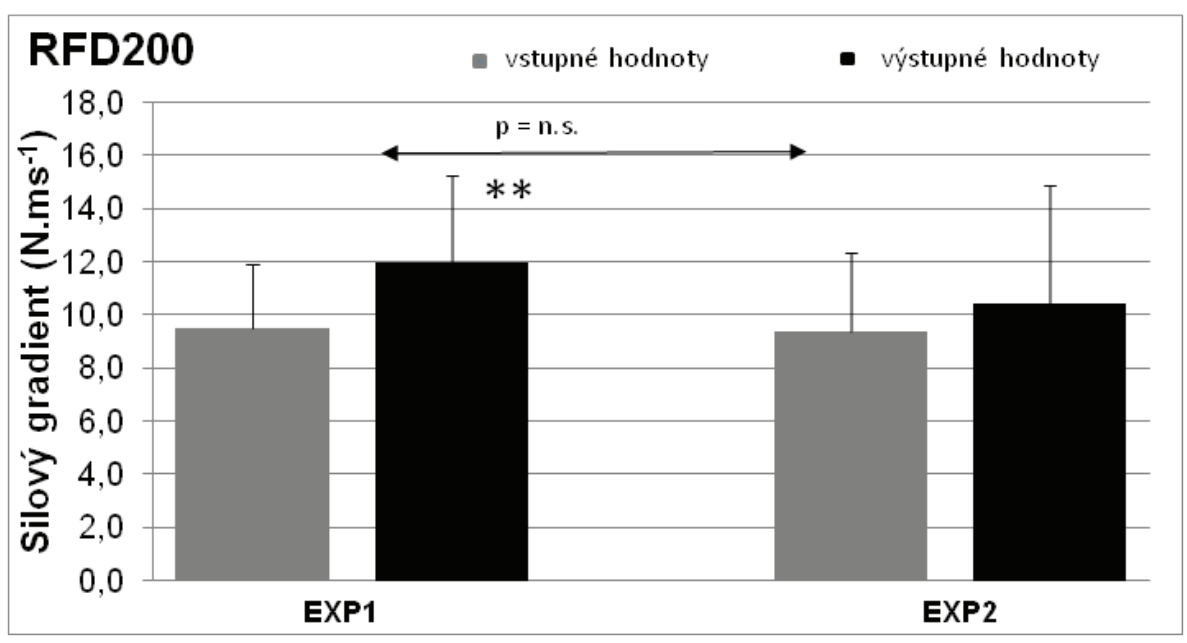

Obr. 8: Priemerné hodnoty a smerodajné odchýlky pri vstupnom a výstupnom meraní v teste ,priemerný silový gradient" $v$ časovom intervale 0-200 ms (RFD200) $\left(*_{-} p<0,01 ; *_{-} p<0,05\right)$

V priemernom silovom gradiente v časovom intervale 0-200ms (RFD200, Obr. 8) sme u skupiny 1 s gradáciou prídavnej hmotnosti (EXP1) zaznamenali vstupné hodnoty 474,676 $\pm 121,31$ N.ms ${ }^{-1}$, výstupné hodnoty 599,948 $\pm 163,51 \mathrm{~N} \cdot \mathrm{ms}^{-1}$. Priemerný prírastok bol po perióde tréningu $2,51 \mathrm{~N} \cdot \mathrm{ms}^{-1}$ a relatívnych hodnotách to bolo 20,91 $\%(\mathrm{p}<0,01)$.

U skupiny $2 \mathrm{~s}$ gradáciou výšky zoskoku (EXP2) sme zaznamenali vstupné hodnoty 468,727 $\pm 149,97$ N.ms${ }^{1}$, výstupné hodnoty $521,013 \pm 224,71 \mathrm{~N} \cdot \mathrm{ms}^{-1}$, probandky sa v priemere zlepšili o $1,05 \mathrm{~N}^{-\mathrm{ms}^{-1}}$, čo v relatívnych hodnotách činilo $10,04 \%$ ( $\mathrm{p}=$ n.s.).

K významnému zlepšeniu RFD200 u EXP1 s gradáciou prídavnej hmotnosti došlo pravdepodobne na základe zvyšovania množstva zapojených motorických jednotiek v aktívnej (koncentrickej) časti pohybu počas tréningového zat'aženia. Väčšie časové oneskorenie (ako pri RFD50) produkcie sily bolo ovplyvnené špecifickou formou adaptácie vplyvom EXP1 podnetov. Spôsobené to mohlo byt' aj nižšou rýchlost'ou pohybu (viac silovorýchlostného charakteru), a tým možnost'ou zapájat' do pohybu aj iné ako tie najrýchlejšie motorické jednotky. Okrem toho tréningové stimuly EXP1 zvyšovali množstvo potenciálnej energie pružnosti, ktorú je možné akumulovat' $v$ excentrickej fáze zat’aženej väčšou hmotnost'ou. Táto špecifická adaptácia sa pozitívne prejavila aj vo výskoku s protipohybom, kde je možné zužitkovat' získanú elastickú energiu. Pri silovom gradiente, ktorý je nevyhnutné merat' v izometrickom režime svalovej práce, sa využívanie elastickej energie privel'mi uplatnit' nedá. Napriek tomu, že meranie RFD sa zdá z hl'adiska špecificity ako nie privel'mi vhodné pre športové hry, treba pripomenút' že silový gradient je jedným z dôležitých ukazovatel'ov rýchlostno-silových schopnosti. Jeho úroveň vysoko koreluje aj so špecifickými prejavmi výbušnosti.

\section{ZÁVERY}

Vo vertikálnom výskoku s protipohybom $(\mathrm{CMJ})$ sme u skupiny s gradáciou prídavnej hmotnosti EXP1 zaznamenali zlepšenie o $1,01 \mathrm{~cm}(3,5 \%)(\mathrm{p}<0,01)$. V prípade EXP2 zmena predstavovala prírastok $1,78 \mathrm{~cm}$ $(5,5 \%)(\mathrm{p}<0,05)$.

Vo vertikálnom výskoku bez protipohybu (SJ) EXP1 sa v priemere zlepšila o $0,94 \mathrm{~cm}(3,5 \%)$ ( $\mathrm{p}=$ n.s.). EXP2 o $1,91 \mathrm{~cm}(6,6 \%)(\mathrm{p}<0,05)$.

$\mathrm{V}$ priemernom silovom gradiente $\mathrm{v}$ časovom intervale 0-50 ms (RDF50) bol priemerný prírastok 
zaznamenaný po perióde tréningu u EXP1 1,03 N.ms ${ }^{-1}\left(26,08 \%\right.$ ) (p=n.s.), EXP2 sme 0,57 N.ms ${ }^{-1}$, v relatívnych hodnotách to bol prírastok o $16,39 \%(\mathrm{p}<0,05)$.

$\mathrm{V}$ priemernom silovom gradiente $\mathrm{v}$ časovom intervale 0-200 ms (RFD200) bol priemerný prírastok po perióde tréningu $2,51 \mathrm{~N}^{-m^{-1}}(20,91 \%)(\mathrm{p}<0,01)$, zatial' čo EXP2 sa v priemere zlepšila o $1,05 \mathrm{~N} \cdot \mathrm{ms}^{-1}(10,04$ $\%)(\mathrm{p}=$ n.s. $)$.

Na základe výsledkov nášho výskumu odporúčame pre zlepšenie úrovne vertikálneho výskoku s protipohybom v tréningovom procese aplikovat' častejšie postup s pridávaním doplnkovej zát’aže v excentrickej časti.

Pre efektívne zlepšovanie výšky vertikálneho výskoku bez protipohybu a kratšie časové intervaly silového gradientu odporúčame $\mathrm{v}$ tréningu používat' systém s postupným zvyšovaním výšky zoskoku.

Tieto odporúčania sú platné pre vyššie úrovne výkonnosti, kde je zložité dosahovat' významné zlepšenia v úrovni výbušnej sily, pretože dlhodobým tréningom je z väčšej časti vyčerpaný adaptačný potenciál. Je potrebné hl'adat' také tréningové prostriedky, ktoré aj na tejto úrovni trénovanosti budú účinné. V našom prípade sme preukázali pozitívny efekt tréningového zat’aženia plyometrického charakteru na výšku vertikálneho výskoku z miesta u vrcholových volejbalistiek. Aj zmena výšky vertikálneho výskoku z miesta na úrovni $2 \mathrm{~cm}$ môže zohrávat' v transformácii do zložitejších pohybových štruktúr dôležitú úlohu v športoch, kde sú rýchlostnosilové schopnosti v štruktúre športového výkonu faktormi limitujúcimi, a to nie iba počas prípravného obdobia.

\section{LITERATÚRA}

Boroujerdi, S.S (2009). Effect of plyometric training on vertical jump performance and neuromuscular adaptation in volleyball players. Journal of Sports Science and Medicine, 8(11):109, ISSN 1303-2968.

Ebben, W.P., Feldmann, C.R., Van der Zanden, T.L., Fauth, M.L., \& Petushek, E.J. (2010). Periodized plyometric training is effective for women, and performance is not influenced by the length of post-training recovery. $J$ Strength Cond Res 24(1):1-7, ISSN 1064-8011.

Escamilla, R.F., Fleisig, G.S., Zheng, N., Barrentine, S.W., Wilk, K.E., \& Andrews, J.R. (1998). Biomechanics of the knee during closed kinetic chain and open kinetic chain exercises. Med. Sci. Sports Exerc. 30:556-569, ISSN 0195-9131.

Hosseini, D. (2012). Effect of plyometric training on vertical jump performance and neuromuscular adaptation. In Volleyball Player. International Journal of Applied Exercise Physiology, 1(2):1-10, ISSN 22322-3537.

Khlifa, R., Aouadi, R., Hermassi, S., Chelly, M.S., Jlid, M.C., Hbacha, H., \& Castagna, C. (2010). Effects of a plyometric training program with and without added load on jumping ability in basketball players. $J$ Strength Cond Res 24(11):2955-2961, ISSN 1064-8011.

Lees, A., \& Fahmi, E. (1994). Optimal drop heights for plyometric training. Ergonomics, 37(1):141-148, ISSN 0014-0139.

Markovic, G. (2007). Does plyometric training improve vertical jump height? A meta-analytical review. British Journal of Sport Medicine. 41(6):349-355, ISSN 0306-3674.

Miller, M.G., Herniman, J.J., Ricard, M.D., Cheatham, C.C., \& Michael, TJ. (2006). The effects of a 6-week plyometric training program on agility. Journal of Sports Science and Medicine, 5:459-465, ISSN 1303-2968.

Potteiger, J.A., Lockwood, R.H., Dolezal, M.D, Almuzaini, K.S., Schroeder, J.M., \& Zebas, C.J. (1999). Muscle power and fiber characteristic following 8 weeks of plyometric training. J Strength Cond Res 13(3):275-279, ISSN 1064-8011.

Schickhofer, P., \& Cvečka, J. (2011). Diagnostika silových schopností I. In: Vzpieranie pre rozvoj sily a kondicie. Bratislava: ICM AGENCY, 98 p.

Slamka, M. (2000). Akumulačno-rekuperačný cyklus svalovej práce a jeho využitie v športe. In: Zborník vedeckých prác katedry atletiky IV. Bratislava : Slovenská vedecká spoločnost' pre TV a šport, pp.13-25.

Steben, R., \& Steben, A. (1981). The validity of the stretch-shortening cycle in selected jumping events. Journal of Sports Medicine. 21: 28-37.

Villarreal, E.S., González-Badillo, J.J., \& Izquierdo, M. (2008). Low and moderate plyometric training frequency produces greater jumping and sprinting gains compared with high frequency. $J$ Strength Cond Res, 22(3):715-725, ISSN 1064-8011.

Zawieja, M. (2008). Leistungsreserve Hanteltraining. Handbuch des Gewichthebens für alle Sportarten. Münster: Philippka-Sportverl. 144 p. 